\title{
GAMBARAN HASIL C - REACTIVE PROTEIN (CRP) PADA NEONATUS YANG DIDUGA SEPSIS DI RSAB HARAPAN KITA
}

\section{JAKARTA BARAT}

\author{
*Prima Nanda Fauziah"1), Mahmudah ${ }^{1)}$, Januar Rhamadani ${ }^{1)}$ \\ ${ }^{1}$ Program Studi Analis Kesehatan, Fakultas Kesehatan, Universitas Mohammad Husni Thamrin \\ Correspondence author: Prima Nanda Fauziah, primanandafauziah@gmail.com, Jakarta, Indonesia
}

\begin{abstract}
ABSTRAK
Neonatus mempunyai risiko tinggi terhadap terjadinya sepsis yang disebabkan sistem imun belum sempurna. Sepsis merupakan keadaan yang serius tetapi jarang menular karena disebabkan oleh bakteri B Stertococcus, Escherichia coli, Liseria, Klebsiella, Enterobacter, Hinfluenza. Hal ini terjadi apabila bakteri mengeluarkan toksin yang menyebabkan sistem imun tubuh melawan organ dan jaringan tubuh sendiri. Tanda-tanda sepsis pada neonatus sulit dinilai sehingga peranan laboratorium sangat penting untuk menegakkan diagnosis sepsis. Sehingga perlu pemeriksaan penunjang menggunakan C-Reactive protein. Penelitian ini bertujuan untuk mengetahui bagaimana gambaran pemeriksaan CRP yang diduga sepsis pada neonatus di RSAB Harapan Kita periode Januari-Desember 2018. Kemungkinan infeksi yang terjadi pada neonatus adalah sepsis neonatorum dan meningitis, aspirasi pneumonia, diare, tetanus neonatorum. Setelah dilakukan penelitian terhadap 203 sampel neonatus, Hasil neonatus yang didiagnosa sepsis terdapat pasien laki-laki lebih banyak yaitu 50,4\% dari pada perempuan yaitu $39,4 \%$.Didapat hasil CRP normal $(<3) 124$ pasien $(54,9 \%)$ sedangkan yang abnormal $(>3) 79$ pasien $(35,0 \%)$, jumlah pasien yang normal lebih banyak yaitu124 pasien $(54,9 \%)$.
\end{abstract}

Kata Kunci : Neonatus, sepsis, C-Reactive Protein

\begin{abstract}
Neonates have a high risk of sepsis caused by the imperfect immune system. Sepsis is a serious but rarely contagious condition because it is caused by the bacteria B Stertococcus, Escherichia coli, Liseria, Klebsiella, Enterobacter, Hinfluenza. This occurs when bacteria secrete toxins that cause the body's immune system to fight off the body's own organs and tissues. Signs of sepsis in neonatals are difficult to assess so the role of the laboratory is critical to enforcing the diagnosis of sepsis. So it is necessary to check support using C-Reactive protein. This research aims to find out how crp examination of suspected sepsis in neonatal at RSAB Harapan Kita period January-December 2018. Possible infections that occur in neonates are neonatorum sepsis and meningitis, aspiration pneumonia, diarrhea, neonatorum tetanus. After research on 203 neonatal samples, neonatal results diagnosed with sepsis found that there were $50.4 \%$ more male patients than women, which was $39.4 \%$. Normal CRP results $(<3) 124$ patients $(54.9 \%)$ while abnormal $(>3) 79$ patients $(35.0 \%)$, the number of normal patients was 124 patients $(54.9 \%)$.
\end{abstract}

Keywords : Neonate, Sepsis, C-Reactive Protein

Open Journal System (OJS): journal.thamrin.ac.id

http://journal.thamrin.ac.id/index.php/anakes/issue/view/36 


\section{PENDAHULUAN}

Bayi baru lahir (neonatus) adalah masa kehidupan pertama di luar rahim sampai dengan usia 28 hari (Depkes RI; 2002). Neonatus mempunyai risiko tinggi terhadap terjadinya sepsis yang disebabkan sistem imun belum sempurna (Schelonka \& Infante,1998 ; Yoder, 1996 ; Radetsky, 1998). Untuk menegakan diagnosis sepsis neonatorum tidaklah mudah karena gejala klinis sepsis pada neonatus tidak spesifik dan sering kali sama dengan gejala klinis akibat gangguan metabolik, hematologik, dan susunan syaraf pusat. Sepsis merupakan keadaan yang serius tetapi jarang menular karena disebabkan oleh bakteri. Hal ini terjadi apabila bakteri mengeluarkan toksin yang menyebabkan sistem imun tubuh melawan organ dan jaringan tubuh sendiri, berbagai kelompok umur dapat mengalami sepsis, tetapi prevelensi tertinggi terserang sepsis adalah bayi dan anak - anak dimana sistem imunnya tidak cukup kuat untuk melawan infeksi yang sangat berat (emedicine2010) dan menurut Ermin dan Tatty (2005:2-3). Mortalitas sepsis berat dinegara yang sudah berkembang menurun hingga 9\%, sedangkan dinegara yang sedang berkembang seperti Indonesia masih sangat tinggi yaitu 50-70\%. Tanda-tanda adanya suatu infeksi bakteri pada bayi yang baru lahir sering tidak jelas atau samar. Oleh sebab itu penderita pada umumnya telah diberi terapi antibioti, jika telah dicurigai infeksi-infeksi tersebut, hingga hasil kultur darah biasanya negatif. Pemeriksaan CRP di serum dapat mementau ada tidaknya suatu infeksi. (Lorens : 1993:8).

C-Reaktif Protein berada dalam darah 6 sampai 10 jam setelah terjadi proses peradangan akut atau kerusakan jaringan atau keduanya, dan mencapai puncaknya antara 48 sampai 78 jam. Pada keadaan tubuh mengalami infeksi, jumlah leukosit meningkat sehubungan dengan fungsinya untuk melindungi tubuh terhadap invasi masuknya benda asing, termasuk bakteri dan virus (Sloane, 2003: 223), sementara peningkatan kadar $C$ - Reaktif Protein terjadi pada infeksi karena bakteri. Jumlah leukosit yang tinggi tidak selalu diikuti meningkatnya kadar $C$-Reaktif Protein. Ada anggapan dari beberapa klinisi bahwa meningkatnya jumlah leukosit harus diikuti dengan meningkatnya kadar $C$ - Reaktif Protein. Untuk menilai kadar CRP dianjurkan setiap interval 12 jam. Pada jam dan hari pertama setelah dimulai terapi antibiotik kadar CRP dapat terus meningkat sampai efek terapi antibiotik tercapai, barulah kadar CRP menurun (Lorens:1993:8) .

Beberapa komplikasi kehamilan yang dapat meningkatkan risiko terjadinya sepsis pada neonatus antara lain perdarahan, demam yang terjadi pada ibu, infeksi uterus atau plasenta, ketuban pecah dini (sebelum 37 minggu kehamilan), ketuban pecah terlalu cepat saat melahirkan (18 jam/lebih sebelum melahirkan),proses kelahiran yang lama dan sulit. (bejocommunity2010).

Berdasarkan banyaknya permintaan tes CRP pada neonatus di RSAB Harapan Kita maka peneliti ingin mengetahui bagaimana gambaran hasil tes CRP yang diduga sepsis pada neonatus di RSAB Harapan Kita dengan mengukur kadar CRP pada kasus tersangka sepsis neonatus sebagai alternatif parameter yang cepat, sensitif, spesifik untuk menegakkan diagnoga sepsis neonatus.

Open Journal System (OJS): journal.thamrin.ac.id 


\section{METODE PENELITIAN}

Penelitian dilakukan di Laboratorium RSAB Harapan Kita Jakarta Barat yang dilakukan dibulan Juli-Agustus 2019. Populasi penelitian adalah data hasil pemeriksaan CRP yang diperiksa kelaboratorium RSAB Harapan Kita. Sedangkan sampelnya adalah data hasil pemeriksaan CRP pada neonatus di Laboratorium RSAB Harapan Kita dari bulan Januari - Desember 2018.

Pengumpulan data dilakukan dengan pengambilan data sekunder hasil pemeriksaan CRP yang diduga sepsis pada neonatus dengan langkah-langkah berikut :

1. Mengajukan izin penelitian dan memberikan proposal KTI.

2. Menunggu balasan dari Diklit RSAB Harapan Kita.

3. Mengambil data di laboratorium dan melihat catatan rekam medis pasien neonatus (persalinan).

4. Mencatat data hasil pemeriksaan CRP pada neonatus dengan melihat buku induk hasil pemeriksaan laboratorium, serta data pendukung lainnya.

5. Dilakukan pengolahan data dan disajikan secara deskriptif.

Data yang diperoleh pada penelitian ini akan disajikan secara deskriptif.

\section{HASIL DAN PEMBAHASAN}

\section{Hasil Penelitian}

Berdasarkan data hasil pemeriksaan terhadap 203 pasien (lampiran 1) suspek sepsis yang melalukan pemeriksaan C-Reactive Protein (CRP) di RSAB Harapan Kita Jakarta Barat pada periode bulan Januari - Desember 2018, di dapatkan hasil seperti di bawah ini :

Tabel 1.

Data karakteristik pasien sepsis neonatus berdasarkan jenis kelamin di RSAB Harapan Kita periode tahun 2018.

\begin{tabular}{ccc}
\hline Jenis Kelamin & Frekuensi & Persen \% \\
\hline Laki-laki & 114 & 50,4 \\
Perempuan & 89 & 39,4 \\
Jumlah & 203 & 100,0
\end{tabular}

(Sumber : Data Sekunder, 2018)

Pada Tabel 1. menunjukkan bahwa jumlah sampel penelitian berjumlah 203 pasien (lampiran 1) yaitu laki-laki sebanyak 114 pasien $(50,4 \%)$ dan perempuan sebanyak 89 pasien $(39,4 \%)$.

Open Journal System (OJS): journal.thamrin.ac.id

http://journal.thamrin.ac.id/index.php/anakes/issue/view/36 
Tabel 2.

Data distribusi frekuensi C-Reactive Protein (CRP) pasien sepsis neonatus di RSAB Harapan Kita periode 2018.

\begin{tabular}{ccc}
\hline Hasil & Frekuensi & Persen \% \\
\hline Normal $(<3 \mathrm{Mg} / \mathrm{L})$ & 124 & 54,9 \\
Abnormal $(>3 \mathrm{Mg} / \mathrm{L})$ & 79 & 35,0 \\
Jumlah & 203 & 100,0
\end{tabular}

(Sumber : Data Sekunder, 2018)

Pada Tabel 2. terlihat distribusi frekuensi C-Reactive Protein (CRP) pasien sepsis neonatus, menunjukan bahwa jumlah sampel penelitian berjumlah 203 pasien (lampiran 1), didapatkan hasil pasien normal ( $<3 \mathrm{Mg} / \mathrm{L})$ sebanyak 124 pasien $(54,9 \%)$ dan hasil pasien abnormal ( $>3 \mathrm{Mg} / \mathrm{L})$ sebanyak 79 pasien $(35,0 \%)$.

Tabel 3.

Data distribusi frekuensi $C$-Reactive Protein (CRP) pasien sepsis neonatus menurut usia (hari) di RSAB Harapan Kita periode 2018

\begin{tabular}{ccc}
\hline Umur & Frekuensi & Persen \% \\
\hline 0-3 hari & 124 & 54,9 \\
4-28 hari & 79 & 35,0 \\
Jumlah & 203 & 100,0 \\
\hline
\end{tabular}

(Sumber : Data Sekunder, 2018)

Pada Tabel 3. Terlihat distribusi frekuensi C-Reactive Protein (CRP) pasien sepsis neonatus menurut usia, menunjukan bahwa jumlah sampel penelitian berjumlah 203 pasien (lampiran 1), didapat hasil neonatus umur 0-3 hari sebanyak 124 pasien (54,9\%) dan hasil neonatus umur 4-28 hari sebanyak 79 pasien $(35,0 \%)$.

\section{Pembahasan}

Pada penelitian ini diperoleh pada Tabel 1, sebanyak 79 (35,0\%) dengan hasil CRP $>3 \mathrm{Mg} / \mathrm{L}$ pasien sepsis neonatus yang ada di RSAB Harapan Kita. Proporsi pasien sepsis neonatus berdasarkan jenis kelamin didapatkan bahwa jenis kelamin laki-laki lebih banyak yaitu 50,4\% dari pada perempuan yaitu $39,4 \%$. Hasil ini juga didapat pada penelitian Setyawati (2006) yang dilaksanakan di RSUP DR. Sardjito 
Yogyakarta yang menunjukan karaktristik sepsis lebih banyak pada jenis kelamin laki-laki. Hal tersebut berhubungan dengan faktor genetik dan kromosom yang berperan penting dalam sistem pertahanan tubuh (Khair,2010).

Berdasarkan distribusi frekuensi C-Reactive Protein (CRP) pada sepsis neonatus pada Tabel 2, didapat hasil CRP normal 124 pasien

( 54,9\%) sedangkan yang abnormal 79 pasien $(35,0 \%)$, jumlah pasien yang normal lebih banyak yaitu124 pasien $(54,9 \%)$ hal tersebut berkaitan dengan kadar CRP yang meningkat selama 24-48 jam maka setelah proses inflamasi menurun kadar CRP akan kembali normal sementara pemeriksaan CRP mungkin dilakukan setelah melewati masa inflamasi tersebut dan CRP merupakan pertanda infeksi non spesifik (Kosasih,2008).

Setelah dilahirkan, bayi dengan cepat menjadi tempat koloni bakteri dan biasanya hal ini tidak berbahaya. Infeksi dapat terjadi jika koloni cukup banyak atau organisme yang masuk memiliki tingkat patogenitas yang tinggi. Bakteri penyebab sepsis neonatus umumnya berasal dari traktus genitalis maternal. Berbagai jenis bakteri dapat ditemukan di dalam traktus genitalia maternal, namun hanya beberapa yang sering menyebabkan infeksi pada neonatus, sedangkan pada ibu tidak menyebabkan penyakit. Infeksi Group B Streptococcus berbahaya dan progresif cepat, sehingga harus dicurigai pada bayi yang memiliki gejala yang menunjang. Organisme lain yang sering menginfeksi adalah Eschericia coli, Listeria, Klebsiella, Enterobacter, H. Infuenza. Dalam penelitian ini tidak dapat dibahas tentang bakteri penyebab sepsis,karena tidak didapatkan data pada rekam medis (Roy \& Simon : 2003).

Namun dalam penelitian ini memiliki keterbatasan data penyebab sepsis pada neonatus yang tidak didapat dari rekam medis RSAB Harapan Kita, sehingga untuk mengetahui perlu dilakukkan kultur bakteri untuk mengetahui penyebab sepsis. Pada umumnya infeksi yang terjadi pada neonatus disebabkan masuknya mikroorganisme ke dalam tubuh seperti bakteri, virus, jamur, parasit. Pemeriksaan CRP hanya pemeriksaan penunjang.

Peningkatan CRP tidak spesifik untuk suatu penyakit tertentu dan harus selalu diinterprestasikan bersama dengan gambaran klinis. Untuk mendapatkan korelasi klinis yang baik kadar CRP harus diperiksa secara serial dan kuantitatif.

Disarankan bahwa pemeriksaan tunggal tingkat CRP dalam diagnosis infeksi. Pemeriksaan seperti ini sangat penting khusus bayi baru lahir yang tanpa gejala atau hanya memiliki tanda-tanda samar-samar pada waktu lahir namun memiliki faktor risiko untuk infeksi. Hasil CRP dapat meningkat juga pada keadaan non infeksi seperti aspirasi mekoneum, nekrosis jaringan, vaksinasi dan operasi. Adanya reaktan fase akut yaitu CRP (konsentrasi tertinggi dilaporkan pada infeksi bakteri, kenaikan sedang didapatkan pada kondisi infeksi kronik). CRP juga akan meningkat dua kali tiap 12 jam (Mathai, dkk, 2010).

Berdasarkan distribusi usia didapatkan jumlah terbanyak umur 0-3 hari sebanyak 124 pasien $(54,9 \%)$ dan hasil umur 4-28 hari sebanyak 79 pasien (35,0\%). Pada penelitian Dian (2017) yang dilaksanakan 
di RSU PKU Muhammadiyah Yogyakarta menyebutkan bahwa berdasarkan usia, proporsi bayi dengan sepsis yang berumur 0-3 hari lebih banyak sedangkan usia 4-28 hari. Sepsis terdiri dari sepsis neonatus awitan dini (SNAD) yang terjadi dalam 72 jam dan sepsis neonatus awitan lambat (SNAL) yang terjadi $>72 \mathrm{jam}$. Sepsis neonatus awitan dini biasanya diperoleh pada saat proses kelahiran atau in utero. Infeksi terjadi secara vertikal karena penyakit ibu atau infeksi yang diderita ibu selama persalinan atau kelahiran bayi, sedangkan sepsis neonatus awitan lambat disebabkan oleh kuman yang berasal dari lingkungan sekitar bayi, proses infeksi seperti ini disebut infeksi dengan transmisi horizontal dan termasuk didalamnya infeksi karena kuman nasokomial. Tingginya presentase pada usia 0-3 hari karena daya tahan tubuh neonatus usia tersebut masih belum sempurna, incidance rate sepsis neonatus awitan dini sebesar 3,5 kasus per 1000 kelahiran hidup dan 15-50\% pasien tersebut meninggal. Perjalanan penyakit SNAD biasanya lebih berat, dan cenderung menjadi fulminal yang berakhir dengan kematian (Aminullah 2007) .

\section{SIMPULAN}

Dari penelitian yang di RSAB Harapan Kita periode 2018 dapat disimpulkan : Hasil neonatus yang didiagnosa sepsis terdapat pasien laki-laki lebih banyak yaitu 50,4\% dari pada perempuan yaitu 39,4\%. Didapat hasil CRP normal (<3)124 pasien ( 54,9\%) sedangkan yang abnormal ( $>3) 79$ pasien $(35,0 \%)$, jumlah pasien yang normal lebih banyak yaitu124 pasien (54,9\%). Didapat hasil neonatus umur 0-3 hari sebanyak 124 pasien $(54,9 \%)$ dan hasil neonatus umur 4-28 hari sebanyak 79 pasien $(35,0 \%)$.

\section{UCAPAN TERIMA KASIH}

Penulis mengucapkan terima kasih kepada RSAB Harapan Kita dan Prodi D III Analis Kesehatan Universitas MH Thamrin berperan serta dalam penelitian ini.

\section{DAFTAR PUSTAKA}

1. Aminullah A,2008, sepsis pada bayi baru lahir, Dalam: Kosim MS, Yunanto A, Dewi R, Sarosa GI, Usman A, Buku Ajar Neonatologi Edisi 1, Jakarta : Badan Penerbit IDAI.

2. Arkhaesi. 2008, Kadar Malondialdehyde (Mda)Serum Sebagai Indikator Prognosis Keluaran Pada Sepsis Neonatorum, Semarang : Fakultas Kedokteran Universitas Dipenogoro.

3. Baratawidjaja. K. G. , Imunologi dasar, edisi ke-6, FKUI, Jakarta, 2004.

4. Baratawidjaja, K dan Rengganis, I. 2014, Imunologi Dasar Edisi ke-11 (Cetakan ke-2), Jakarta : Balai Penerbit FKUI. 
5. Depkes RI, Manajemen Kebidanan, Depkes RI, Jakarta,2002 ; 1-2.

6. Departemen Kesehatan RI, Profil Kesehatan Indonesia, Jakarta, 2008.

7. Frances K. Widaman. 2009. Tinjauan Klinis Atas PemeriksaanHasil Laboratorium. Jakarta : Penerbit Buku Kedokteran EGC.

8. Juniatininingsih A, Aminulah A, \& Firmansyah, A. 2008, Profil Mikroorganisme Penyebab Sepis Neonatorum. Sari Pedati, Vol. 10, No. 1, Juni 2008, Jakarta: Divisi Perinatologi, Departemen IImu Kesehatan Anak FKUI/RSCM.

9. Lab technologist. 2009. Protein C-Rektif, Laboratorium Kesehatan. Tersedia dalam : http://labkesehatan.com/2009/11/protein-c-reaktif.Html

10. Lever A, Mackenzie I. 2007. Sepsis: Definition, Epidemiology, and Diagnosis. BMJ

11. Menkes RI, 2012. Profil Kesehatan Indonesia Tahun 2012. Jakarta : Kementrian Kesehatan Republik Indonesia.

12. Menkes RI, 2015. Profil Kesehatan Indonesia Tahun 2015. Jakarta : Kementrian Kesehatan Republik Indonesia.

13. Matondang dkk,2013. Diagnosis Fisik Pada Anak. Jakarta : CV aung seto.

14. Pusponegoro TS. 2000. Sepsis Pada Neonatus (sepsis neonatal). Sari Pediatri 2000; 2:96.

15. Sacher R, McPherson R; Tinjauan Klinis Pemeriksaan Laboratorium, Ed 11,EGC,Jakarta, 2002.

16. Schelonka, R. L, Infante, A.J,Neonatal Immunology, Semin Perinatal,1998 ; 22:2-14.

17. Whicher J, The Acute Phase Respon and C-Reactive Protein. Serum Protein in Clinical Medicine, 1996.

18. www.bejocommunity.com 21/06/2010.infeksi neonatus_

19. www.emedicine.com, 21/06/2010, sepsis. 